\title{
THE WORK OF THE GENERAL FEDERATION OF WOMEN'S CLUBS AGAINST CHILD LABOR
}

Mrs. A. O. Granger,

Chairman of Child Labor Committee, General Federation of Women's Clubs, Cartersville, Ga.

The work of the General Federation of Women's Clubs for the prevention or lessening of child labor is of a many-sided character. Primarily it consists in arousing the members of the clubs to a consciousness that the industrial conditions surrounding the women and children who must toil for bread, are quite as much a part of our responsibility as if we were their employers. Purchasing and enjoying the fruits of their labor, we have only of late years realized that to us is partly due the suffering borne in producing the results. And this realization has been largely the result of the work of the National Consumers' League.

Not all women's clubs are for the study of sociological conditions; there are studies of many kinds, and clubs of many varieties, but whether the studies be of one kind or another all club women have hearts. When once those hearts have opened to the suffering of the children the motherhood inherent in woman responds to the call-she listens to the "Cry of the Children" who are wearing out their lives in unwholesome work-and listening and studying, the club women have learned many things!

The suggestions which have been made to the clubs by their "Child Labor" Committee are eminently practical and all leading up to the final attainment of freedom for the children to obtain their growth before engaging in work which dwarfs both body and mind if pursued at too early an age. In 1903 the following letter was sent to all federated clubs:

Dear Madam Fresident: During the past year marked advance has been made in securing child labor legislation throughout the states of the Union. Women's clubs have been active in this movement which has con-

$$
\text { [516] }
$$


sisted both in enacting new laws and in amending old ones. The argument against this legislation which has been most universally encountered has been that the earnings of little children are needed to support widowed mothers. The Committee on Child Labor is convinced that the argument has been unfairly used, that the number of poor widows in any community is limited, and that among that limited number there are comparatively few whose oldest children are between the ages of ten and fourteen years, - the time when the temptation to use the premature labor of children is strongest. Nothing could be more valuable to the cause of child labor than to lay this ghost which has so long frightened many of the sincere friends of little children, and has furnished the basis of the emotional appeal so often used against sober argument.

Your committee therefore earnestly requests that the women's clubs throughout the country aid the cause of child labor by securing information as to the number of working children between the ages of ten and fourteen years, whose mothers are widows, who are in any wise dependent upon the earnings of their children, and also the number of those mothers, and the amount of wages of the child, so far as it may be ascertained. The committee would advise the City Federations of Women's Clubs to meet and partition the manufacturing districts of each city among the clubs, using as the basis of their investigation the records of the public and parochial schools, the factory inspector's office, and charitable societies. In the smaller towns and villages the problem will be much simpler; and if a number of communities are investigated the information thus secured will be most valuable.

The committee requests those clubs who wish to do more than investigate to take the following action:

Whenever possible to persuade the children thus employed to return to school, undertaking to pay the amount of the weekly wage which the child formerly earned to his widowed mother every Saturday night upon presentation of a certificate signed by the child's teacher testifying to his regular school attendance the entire five days of the previous week, - - the money to be called a scholarship. This plan greatly resembles one in successful operation in Switzerland for twenty-five years, where it is carried on by the state authorities.

Such action will tend to interest the club women in the welfare of mill operatives, and should in time help to establish permanent home keeping among those who have.so largely formed a floating element in the population, especially in the new mill towns of the South.

Signed by the committee.

JANE AdDAMs, Chairman.

At the Biennial, held in St. Louis, in May, 1904, the General Federation recommended to the State Federations and federated clubs that in all states in which children work at night and children work who cannot read and write in the English language, the effort 
of the clubs should be concentrated upon the passage of laws covering these points, namely:

I. That children under the age of 16 years should not work between the hours of 7 p. m. and 7 a. m.; and,

2. That children should not work who cannot read and write in the English language.

3. In states in which these two points are already covered by effective laws, the adoption of the Standard Child Labor Law is recommended, including the Newsboys' Law.

The suggestions for this year's work will be in the same linefor it is "line upon line" in child labor as in all other work. Please notice carefully the points of these suggestions. Many of the "widowed" mothers are such in name, because the idle father has betaken himself to parts unknown in order to shirk the responsibility of his family! And have you visited the factory towns and seen the anxious mothers? No wonder that the baby workers look old before they are grown; their mothers, too, knew perhaps no carefree childhood-they worked before their growth was completed, and the children have the heritage of weakness.

Do you remember the old lines:

$$
\begin{aligned}
& \text { "Childhood should be all divine, } \\
& \text { Mother, dear, } \\
& \text { And like an endless summer shine-- } \\
& \text { Therefore bid thy song be merry, } \\
& \text { Mother, dear!" }
\end{aligned}
$$

But there is no room for merriment, and childish glee, and mother-joy, when by the laziness of a father the little ones must go to the mill day after day, and then turn night into work-time and walk up and down by the machines until a dash of water into their faces tells them that they were going to sleep and the inspector had thus aroused them! Club women are learning many things. It is but a few weeks since a friend told me of seeing a father who showed no sign of weakness take six of his children to a mill for work-he himself claimed to be too feeble to do regular worka "vampire father," as such men are now called, living upon the money earned by the sapping of the vital forces of his children!

In the state of Pennsylvania is the ground consecrated by the awful "Wyoming Valley Massacre," but what about the "Slaughter $[5 \div 8]$ 
of the Innocents" in the mills of that territory now? Has it been stopped since discovered a little over two years ago?

Unable immediately to control the forces which keep little children at work at the expense of their growth and development, club women are working in many ways to better the condition of the children, and by following their lead many mill owners are now able to boast of the advantages which they give to their operatives in the way of night schools and libraries I wish that you could go with me to visit a night school. The older boys and girls are anxious to obtain the education which they could not get in their childhood; some of them look strong and well, thus proving that they had completed their growth in remote country districts before coming into the mills. But the majority look bleached and tired, and the smallest children make what is often a vain struggle against the utter fatigue which is the result of a long day's monotonous labor. See that little head lying upon the thin arms?-among the brown curls are little bunches of lint, and more still upon the clothing. Can any thoughtful person believe that there are not still finer fibres lying upon the delicate intricacy of the child's throat and lungs?

In the daytime the kindergarten established by the women take the tiniest little ones, and in the happy hours there the tots learn something of the ways of a well-conducted home-things which their mothers are unable to teach them either from lack of time, or strength, or knowledge.

In other places the club women have arranged schools at such hours that those who must carry baskets to the mill may do so without losing any of the precious instruction and influences of the school.

I would not leave the impression that club women regard mill-owners as the sworn foes of childhood. Many managers of mills declare that they would prefer not to use child labor, and where there are laws against it some managers are careful to obey them, but there are others who regard this awful abuse of the children as part of the business and who vehemently fight against any laws being entered upon the statute books, or better laws being substituted for poor ones. In Georgia, in order to take away this excuse for labor legislation, the cotton mill men have agreed among themselves not to employ children under 12 years of age. With 
a conscientious manager this would greatly lessen the evil if there were no lazy fathers who will falsely swear to the age of a child in order to put it into the mill. But it was of that agreement that a club woman heard a tale: Two men on a railroad car were discussing child labor, not knowing that the two women in front of them were members of the Georgia Federation of Women's Clubs. The mill man held that the children would spend their time on the streets playing marbles if they were not at work; the other promptly rejoined that he'd rather have his children in the fresh air than in a lint-laden mill, and added: "But I don't see why you mill men should object to the bill when you've agreed not to employ little children." "Oh," said the other, with a shrug, "that was only for the legislature!"

But the General Federation is working in still other ways against child labor. The supply of children and mothers for mill work is in many cases-certainly in the South-drawn from the tenant class who here, as elsewhere, give evidence of all the weaknesses that come from economic dependence on others and who from their very ignorance are easily persuaded to change their place of living. Therefore, for these reasons among others, the club women are bringing to the rural schools, so often bald and poorly equipped, the industrial training which by its hand work is helping to develop perception, and open the minds of the children to the beauty and pleasure to be found around them. The gardening there taught, and the emulation aroused in the improvement of the homes are doubly important, viewed as a means of creating a love of one spot as home.

The cooking classes for mothers after school hours are often a centre of influence of untold value; there the teacher has the opportunity of becoming well acquainted with mothers who may some day be tempted to move to a mill town. Can we blame their desire to go to a place where they can earn money, and where "the children, too, can help," if they have never heard that such work will prevent the healthy growth of the children?

For such work as this the Massachusetts Federation has donated over one thousand dollars during the last three school years to help the Georgia Federation's work.

The women of the General Federation of Women's Clubs hope soon to see the day when from end to end of our land, whether [520] 
cotton, or silk, or glass, or fruit-canning be the prevailing industry, the fathers must be the ones who must earn the support for the family-when no children under 16 years shall work during the night hours, and when the presence of a boy or girl in a factory of any kind proves that he or she can read and write English, and has reached such a stage in development that the long hours will not dwarf him.

In every state where the evil of child labor exists, club women are using their influence as moulders of public opinion to make it impossible for such a state of affairs to be permanent. In North Carolina, where the legislature has just refused to improve the laws on this subject, a club woman writes that the improvement is only postponed- "It took twenty-five years for us to procure some other reform legislation, so we are not discouraged!" The Illinois Federation has issued a model statement of their present endeavor to prevent the change of the child labor laws and showing what excellent results are attending the working of the present ones, for which they ask a longer trial.

Emerson asserted that civilization was "The power of good women." If this be true, and who can doubt it, how great is the power developing from the seven hundred thousand women bound together for usefulness in the General Federation.

Women are the creators of public opinion, and those federated women are using their influence from sea to sea, and the lakes to the gulf. They are the leaven which requires but time and ardor to lighten the whole mass of working women and children and lift them by the power of growth to higher planes of work and knowledge. 